DOI: doi.org/10.18372/38238

UDC: $665.7 .035(043.2)$

\title{
2.9 THE INFLUENCE OF OXYGEN CONCENTRATION ON THE FIRE SAFETY OF AIRCRAFTS FUEL SYSTEMS
}

\author{
Valeriy Yefymenko, Tetiana Kravchuk, Lidiya Kovshun, Natalya Atamanenko
}

The development of aviation and rocket-space techniques constantly sets new requirements for fuel and lubricant materials, since the quality of fuel and the technology of its preparing for refueling should ensure not only the keeping of physico-chemical indicators with its subsequent long-term storage, but also the chemmotological reliability of the fuel systems operation.

The complexity of ensuring an adequate level of fire safety is that aircrafts use a large amount of hydrocarbon fuels, which requires effective protection for trouble-free operation. A reactive fuels vapor can form explosive mixtures with air under the influence of external factors. They are capable to fire under the influence of the means of military impact, electric discharges, damaged electrical equipment, static electricity discharges or sources of ignition occurred in emergency situations. Thus, knowledge of the conditions for the formation of explosive fuel-air mixtures and the possibility of preventing their formation during operation will allow providing the safety of the fuel systems operation.

One of the possible ways of this problem solving is to remove the dissolved oxygen from fuel in fuel tanks and above fuel space by blowing with nitrogen. Such technology is used very limitedly only for military aviation and rocket techniques. The widespread implementation of this technology for the fuel preparation to refueling in an aircraft is restrained by high nitrogen outlay, high cost of its transportation and the need for additional special containers and equipment for its storage near fuel and lubricant warehouses.

That is why this study of the processes of air (oxygen) dissolution in fuels, the determination of its concentration in the above fuel space of aircraft's fuel tanks and the formation of fuel-air mixtures dangerous to ignition are relevant due to the necessity to provide the chemmotological reliability of aviation techniques fuel systems.

The analysis of fuel systems explosive safety showed that the possibility of ignition of a steam-air mixture of reactive fuels is determined by many factors: the presence of a large number of combustible hydrocarbons, the temperature of their ignition and self-ignition, the concentration and temperature limits of ignition. But the main and determining factor is the presence of air's oxygen which contacts with fuel vapor. When fuel is isolated from oxygen its ignition is impossible under any conditions.

The characteristic feature of fuel systems from the point of view of fire and explosion danger is the change in the fuel level both when stored in a tank in the fuel and lubricants warehouses and in the aircraft's tank during the flight. Fuel combustion takes place in the vapor phase. That is why the volume of the above fuel space increases with jet fuel use from a tank and this space is filled with air and the fire-explosion danger of fuel systems increases [1-4].

The certain correlation between the fuel vapor and oxygen concentration in the air is necessary for ignition the fuel-air mixture, as well as the temperature at which the oxidation reaction may proceed. Combustion of a fuel-air mixture is possible only in the boundaries limited by the upper and lower concentration limits of ignition. The upper concentration limit of ignition for most hydrocarbon fuels is $6-8 \%$ vol., the lower one $-1,0-1,5 \%$ vol. The non-flammability of very rich and very poor mixtures can be explained by the fact that the reaction rate is rapidly reduced because the heat loss into the environment is higher than the heat emission during the limited oxidation reaction because of oxygen or fuel vapor lack.

There are also temperature limits of ignition due to the dependence of fuel vapor concentration in the above fuel space on its partial pressure, which in turn depends on temperature. 
Explosive mixtures formation is possible only at certain temperature intervals, which are limited by the lower and the upper temperatures of fuel ignition. The lower and the upper temperature limits of ignition form the temperature zone of fire-explosion danger.

The temperature limits of fire-explosion danger are not constant for fuels of a certain fraction composition, and vary depending on pressure, i.e., the flight altitude of the aircraft. Moreover, the temperature zone of the fire-explosion danger decreases and shifts towards lower values, because fuels evaporation increases in the result of atmospheric pressure decrease. This factor increases the risk of fuel tanks explosion when an aircraft climbs in altitude.

Foam is formed in the result of mechanical mixing of fuel in reservoirs and aircrafts tanks in dynamic conditions. This foam has a higher propensity to ignition due to higher solubility of oxygen in fuel compared with nitrogen, and its higher concentration in emitted from fuel gases. It has been established that the flame can spread over fuel-air foam at the lower temperature than the fuel flash point.

The dissolved air with increased oxygen content is emitted from fuel with atmospheric pressure decrease during aircraft climbing in altitude. According to this oxygen concentration in the above fuel space increases to $30-35 \%$ vol., and this increases the fire-explosion danger of the fuel system.

Combustion of fuel-air mixtures is an explosion, i.e., it occurs with an instantaneous rate of change their physical and chemical composition, which is accompanied by the release of a large amount of energy. During this the flame spreading rate reaches $10-100 \mathrm{~m} / \mathrm{s}$, the temperature exceeds $1000{ }^{\circ} \mathrm{C}$, the pressure increases to $10 \mathrm{MPa}$, which leads to the complete destruction of the fuel system.

There are two possible ways to ignite the fuel-air mixture. The first one consists in the mixture heating to the temperature of self-ignition, which depends on the chemical composition of fuel and pressure. This occurs when the fuel gets on the heated surfaces of a fuel system or engine part. The second one is the ignition of the fuel-air mixture from the source of open flame inside the fuel tank, due to static electricity discharges, lightning discharges, and in military aviation due to defeat by military means.

It is taken to characterize fire danger of fuel mixtures by the flash point which is $10-15^{\circ} \mathrm{C}$ lower than the lower temperature limit of ignition. Only the fuel-air mixture burns down at a temperature corresponding to the flash point, but the combustion process does not stabilize.

Fire and explosion in fuel tanks can occur only if three constituent conditions are present: fuel, oxidizer and sources of ignition. It is possible to cause the most effective influence only on the oxidizer concentration in the above fuel space. Reducing its concentration to 10-12\% vol. allows to exclude the possibility of fire-explosive mixture formation in the fuel tank, as well as to increase the chemical stability of fuel hydrocarbons.

Static electricity discharges, lightnings, defeat by military means, damage to the electric wire, engine surfaces heated to high temperatures can be sources of activation energy of fuel-air mixtures.

Fuels are dielectric liquids, but when pumped through the system and filtrated they can gain electrical charge. In this case, charges of static electricity are accumulated, the potential difference of which can reach the values of $3000 \mathrm{kV} / \mathrm{m}$ and be higher than the breakdown voltage of the phase separation surface of fuel-air.

The analysis of cases related to accumulation of static electricity in petroleum fuels showed the following causes of explosions and fires in \%: transportation and pumping of fuel -57 ; during pour in and pour out operations with fuel splashing - 16; increased fuel evaporation - 10; fuel pumping at an unacceptably high speed -6 ; discharges on the service equipment shells -6 ; permeation of dust and lightnings -5 . 
Accumulation of electric charges of a dangerous magnitude is caused by the presence of organic impurities in fuels (sulfuric, nitrogeneous, oxygen-containing compounds and pitch), and non organic (water, mechanical impurities).

The minimum spark discharge energy, sufficient for the mixture ignition, should be $0,20-$ $0,25 \mathrm{MJ}$. At the same time, the spark discharge is possible at a voltage of 300-330 V at some cases. Electrical discharges occur on sharp edges, protrusions of the sensors in the the tanks upper part.

A dangerous factor influencing flight safety is an of action external static electricity besides internal. It occurs on the aircraft's body as a result of its interaction with charged parts in the atmosphere - water drops, dust, ionization radiation.

Thunderstorm discharges are also very dangerous for fuel systems. Aircrafts are struck by lightning on average over every 2400 hours of flying at European Airlines. Mechanical and thermal damage can appear in the result of lightning striking, resulting in an flash and explosion of fuel vapor.

Military airplanes can be further affected by combat means, rocket fragments, inflammatory bullets.

It is impossible to completely exclude the possibility of formation of a ignition source of a fuel vapor in the above fuel space in the current conditions of aviation development. But we can reduce partially this influence by applying antistatic additives, grounding aggregates and pipelines, limiting the pumping and refueling speed.

Reducing the oxidant amount or fuel vapor in the above fuel space of fuel tanks or fuel vapors prevents the possibility of an explosive mixture formation and thereby the occurring of a fire and explosion.

Like any liquid, reactive fuels can dissolve gases, including oxygen contained in the air. The air and its gases permeate into the fuel in two ways: dissolving in the process of diffusion and when stirring. Accordingly, the maximum concentration of oxygen in the fuel is observed after its filtration.

The solubility of gases in liquids depends on partial pressure. As the pressure decreases, the solubility of gas in hydrocarbons also decreases, which causes its emission into the above fuel space. The solubility of oxygen, nitrogen and other gaseous air components is proportional to the partial pressure of each of them under these conditions. The solubility coefficient of oxygen in the jet fuel is almost twice higher than the nitrogen solubility coefficient. As a result, oxygen dissolves in fuel in a greater proportion than nitrogen compared with their ratio in the air. Therefore, the gas mixture emitted from fuel is more oxygen-rich than conventional air. The volume ratio of nitrogen to oxygen is $2.07: 1$ in it, while in the air it is $3.76: 1$.

Air with oxygen content $30 \%$ vol. is emitted from fuel at the altitude $8000 \mathrm{~m}$, therefore the explosion danger of the fuel system increases significantly. It also increases the fire-explosion danger limits of fuel-air mixtures.

The solubility of air in fuels decreases with temperature increase, especially during supersonic flights. The influence of temperature on gases solubility can be explained by the principle of Le Chatelier: with temperature increase the process that weakens its growth, that is, endothermic, intensifies. Gas emission from the solution is such process, the solubility decreases due to this process intensification.

The lower temperature limit of fire-explosion dangerous mixtures is a minimum fuel temperature at which a combustible mixture capable to ignite from external source of energy in a closed volume of the above fuel space may be formed. If the fuel temperature in a tank will decrease, the concentration of fuel vapor in the air will also decrease and the mixture will become non fire-explosion dangerous.

The upper temperature limit is the maximum temperature of fuel at which the mixture of fuel vapors with air still retains fire-explosion dangerous properties. With further rise in temperature, the mixture becomes oversaturated with fuel vapor and stays fire-explosion safe. 
Concentration limits of the flash are limiting concentrations of fuel vapors in the air, at which the flashing of fuel vapor and air mixture and further spread of flame is possible.

The equipment for determination of the concentration and temperature limits of fireexplosion danger of fuel-air mixtures has been developed; its principal scheme is shown in Fig. 1.

The equipment consists of a chamber 1 , which has the heater 2 on its outer surface connected through an autotransformer 3 to a voltage of $220 \mathrm{~V}$ of an alternating current. The chamber is protected from the environment by a heat-insulating material 4 to reduce the heat exchange. The chamber is closed with a cover and sealed with a gasket of gas-resistant rubber. The heating of the chamber is carried out by autotransformer 3 , and cooling - by blowing with liquefied nitrogen from the Dewear vessel. The top cover of the chamber is equipped with a thermocouple 19, which sends a signal to the temperature recorder 20. The ignition source of the vapor-air mixture is the spark discharge, which is formed between electrodes of the spark plug 8 by pressing on the push-button switch 9 . The ignition coil 10 is used as a high voltage source, the voltage on it is fed from the power supply unit 13 . The pressure impulse from the explosion of the vapor-air mixture is detected by the pressure sensor 15 and registered by the self-recording device 16 .

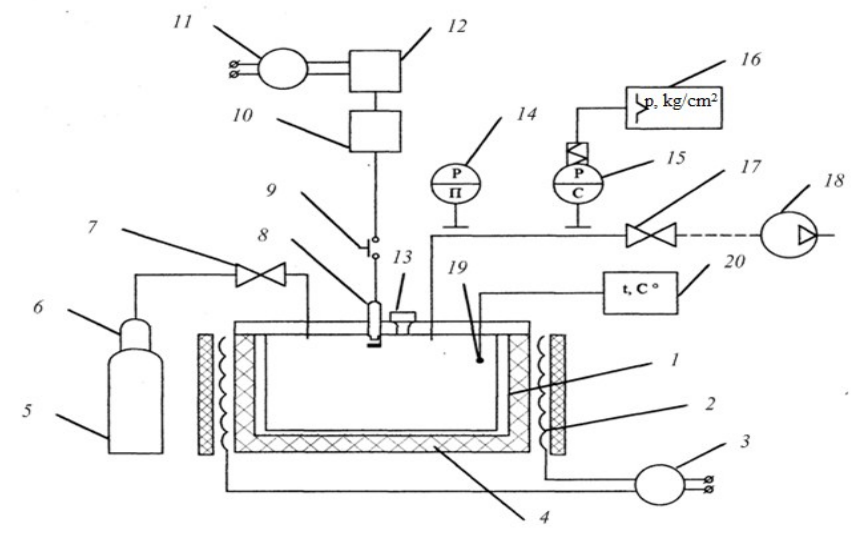

Fig. 1. The basic scheme of equipment for determination the temperature limits of the formation of flammable fuel-air mixtures: 1 - chamber; 2 - heating element; 3,11 - autotransformer; 4 - heat-insulating material;

5 - cylinder with compressed air; 6 - reducer with high and low pressure manometers; 7,17 - faucets;

8 - spark plug; 9 - push button switch; 10 - ignition coil; 12 - voltage stabilizer; 13 - sampler;

14 - manometer; 15 - pressure sensor; 16 - self-recording device; 18 - vacuum pump; 19 - thermocouple; 20 - temperature recorder

Accumulated after the explosion gases in the above fuel space are taken from the chamber by blowing air from the cylinder 5 , equipped with a reducer 6 with manometers of high and low pressure. In this case, faucets 7 and 17 are in the open position. Sampling from the above fuel space is carried out through a sampler 13 . Gases samples are analyzed by the chromatographic method for the determination of oxygen content in them.

The chromatographic method is used for determination the volumetric content of oxygen, nitrogen, and also products of fuel combustion.

A vacuum pump 18 is connected to the outlet nozzle of the faucet 12 for the study the temperature limits of the formation of combustible mixtures with aircraft climbing to the altitude. The dilution in the chamber is created depending on the flight altitude (by the international standard atmosphere) and is controlled by a monovacuummeter 14 .

Thus, it is possible to carry out investigation of the influence of oxygen concentration, neutral gases, flight altitude, concentration of fuel vapor on temperature and concentration limits of 
the formation of fire-explosive dangerous mixtures and the magnitude of a pressure impulse from their explosion with the help of the designed equipment.

Investigation of the influence of increased oxygen concentrations on the temperature limits of the formation of explosive mixtures was carried out by blowing the test chamber's above fuel space with oxygen, the influence of decreased concentrations - by blowing with nitrogen, with following chromatographic method for determination oxygen concentration in the above fuel space.

Explosive mixtures of fuel vapor and air can only be formed at certain temperature intervals and oxygen volume fraction of in the above fuel space. The study was carried out on fuels RT and Jet A-1 with constant oxygen content in the above fuel space equals to $21 \%$. The experimental data (Fig. 2a) shows, that the lower temperature limit for the formation of combustible mixtures for fuels coincides with their flash point and is $38{ }^{\circ} \mathrm{C}$. These fuels have practically the same fractional composition, that is why, and their flash points are equal.

We can observe the decrease of oxygen concentration up to $12 \% \mathrm{vol}$. and the impulse pressure increase up to $0,8 \mathrm{~kg} / \mathrm{cm}^{2}$. The pressure impulse increases with further heating due to increase the fuel vapor volume fraction, which takes part in an oxidation reaction. It can be explained by the further decrease of oxygen's residue concentration.

The maximum of the pressure impulse corresponds to the lowest concentration of residual oxygen in the above fuel space after the explosion, and it is stable for jet fuels at temperature intervals $43-52{ }^{\circ} \mathrm{C}$. With further increase in temperature, the fuel concentration increases so much, that there in not enough oxygen to start the reaction of ignition of the fuel-air mixture. The upper temperature limit of the flash is $58{ }^{\circ} \mathrm{C}$ for fuels RT and Jet A-1.

Thus, the lower limit of formation of combustible mixtures for the most common reactive fuels is $38{ }^{\circ} \mathrm{C}$, and the upper one is $58{ }^{\circ} \mathrm{C}$. The lower and upper temperature limits of the explosion danger form a so-called, temperature zone of fire-explosion danger, which primarily depends on oxygen concentration in the above fuel space. The safe fuel temperature is $10-15{ }^{\circ} \mathrm{C}$ below the lower and higher the upper temperature limits of the flash due to the fact that intense evaporation and the evolving of dissolved gases from the fuel takes place at real flight conditions under vibrations and stirring.

The decrease of oxygen concentration in the above fuel space to $15 \%$ vol. (Fig. $2 b$ ), which is achieved by blowing with neutral gas, leads to a slight shift of the flash start temperature towards lower values.

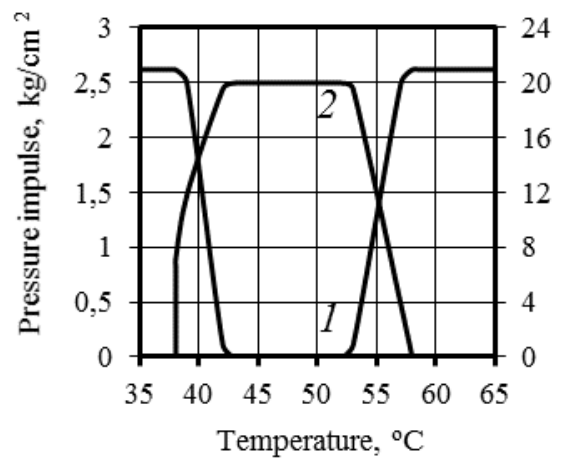

(a)

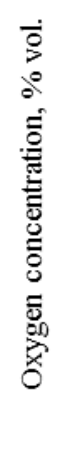

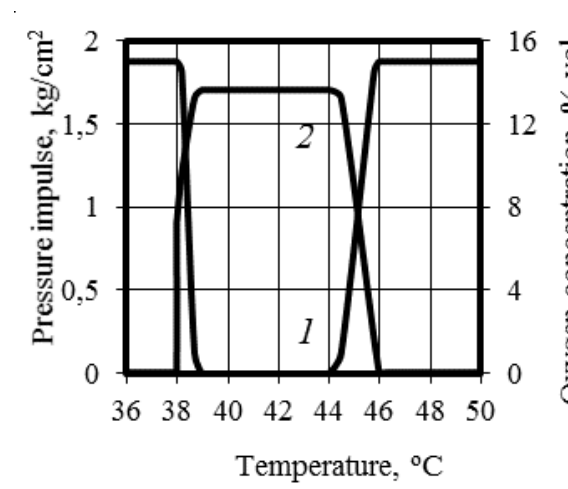

(b)

Fig. 2. Dependence of the temperature limits of the formation of combustible mixtures and the pressure impulse from the initial oxygen concentration in the above fuel space of $21 \%$ vol. (a) and $15 \%$ vol. (b): 1 - oxygen concentration; 2 - pressure impulse 
The temperature zone of explosive mixtures formation becomes even narrower and equals to $38-40{ }^{\circ} \mathrm{C}$ for the studied fuels with further reducing oxygen concentrations to $13 \%$ vol. (Fig. 3).

The flash of fuel-air mixtures does not occur at oxygen concentration in the above fuel space less than $12 \%$ vol.

It is necessary to mention that with change of oxygen concentration from $21 \%$ vol. to $12 \%$ vol. the lower limit of explosion danger at ground conditions varies on $1-3{ }^{\circ} \mathrm{C}$, while the upper limit varies on $25-30{ }^{\circ} \mathrm{C}$.

The determining factor in the flash process of fuel vapor is the flight altitude, which simultaneously affects two factors: the volume content of fuel vapor and oxygen concentration of in the above fuel space.

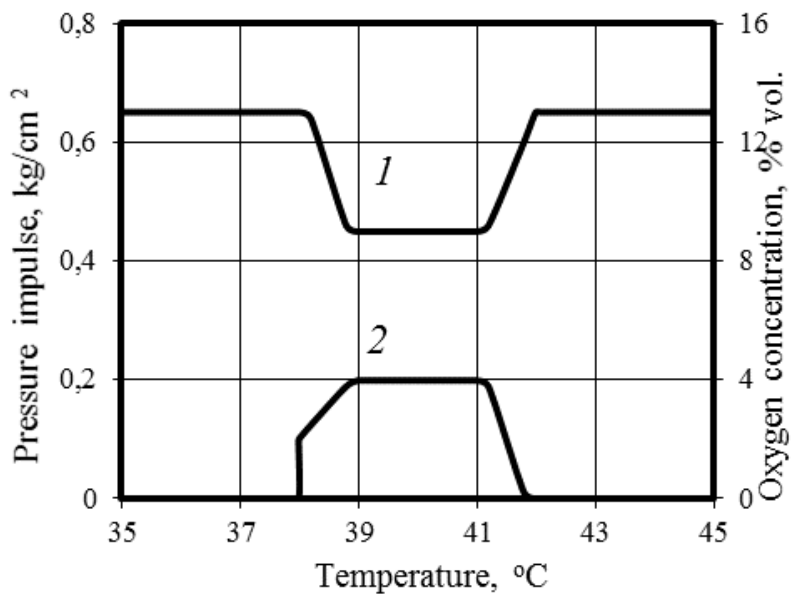

Fig. 3. Dependence of the temperature limits of combustible mixtures formation and the pressure impulse from the initial oxygen concentration in the above fuel space $13 \%$ vol. for fuel RT, Jet A-1:

1 - concentration of oxygen; 2 - pressure impulse

When the aircraft climbs in altitude the temperature limits of combustible fuel-air mixtures formation of depend on the concentration of oxygen in the above fuel space. In ground conditions the minimum oxygen concentration at which an explosion is still possible is $12 \%$ vol., than at an altitude of $5000 \mathrm{~m}$ is $15 \%$ vol., and at an altitude of $10000 \mathrm{~m}$ is $17 \%$ vol. An increase of oxygen concentration above these values extends the temperature zone of explosion danger.

The lower temperature limit of explosion danger is slightly depends on changes in oxygen concentration at different altitudes; it can be explained by the lack of fuel vapor for oxygen excess, i.e., the mixture is poor. Therefore, the change in oxygen concentration of practically does not affect the lower temperature limit of explosion danger. The upper temperature limit greatly depends on oxygen concentration in the above fuel space; it can be explained by the high vapor content and the lack of oxygen. That is why even a slight change in oxygen concentration significantly affects the upper temperature limit of explosion danger.

The increase of oxygen concentration to $30 \%$ vol. in the above fuel space, by its emission from fuel, practically does not affect the flash lower temperature limit. But the flash upper temperature limit is greatly expanded. So, when oxygen concentration is $21 \%$ vol. in the above fuel space, it equals to $58{ }^{\circ} \mathrm{C}$ for the studied fuel, when concentration is $25 \%$ vol. $-74{ }^{\circ} \mathrm{C}$, and when $30 \%$ vol. $-96{ }^{\circ} \mathrm{C}$. The increase and expanding of the maximum pressure impulse range also takes place, and it can reach destructive values for the aircraft design.

It has been experimentally proved (Fig. 5) that with an aircraft climbing in altitude the explosion danger zone shifts towards lower temperature limits, due to increase of fuel evaporation 
in the result of atmospheric pressure reduction; that is why dangerous concentrations of fuel vapor are formed at lower temperatures.

Since the lower temperature limit of explosive mixtures formation is characterized by an excess of oxygen and a lack of fuel vapor, the flash temperature does not significantly depend on oxygen concentration and the fuel temperature, whereas the upper zone of explosion danger depends considerably on temperature at all flight altitudes.

Analysis of graphic dependencies shows that with increase the aircraft's flight altitude, the permissible concentration of oxygen in the abovefuel space in a fuel tank increases, if its explosion safety is provided. The maximum permissible concentration of oxygen in fuel tanks depending on the flight altitude, taking into account the guaranteed exception of fuel-air mixture flash $(2 \% \mathrm{vol}$. less than the minimum oxygen concentration for the formation of a combustible mixture) has the following values: in ground conditions $(0 \mathrm{~m})-10 \%$ vol.; $5000 \mathrm{~m}-12 \%$ vol.; $10000 \mathrm{~m}-15 \%$ vol; $15000 \mathrm{~m}-21 \%$ vol.

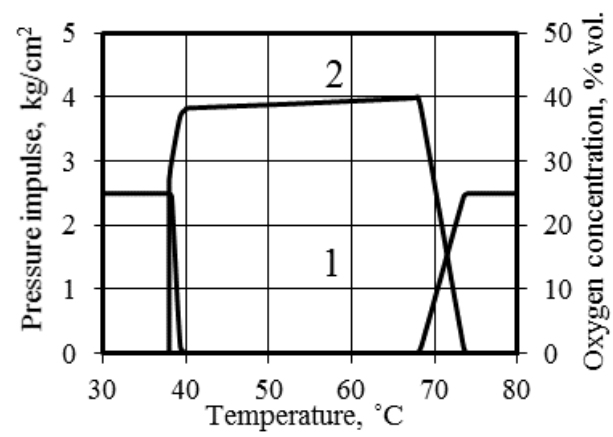

(a)

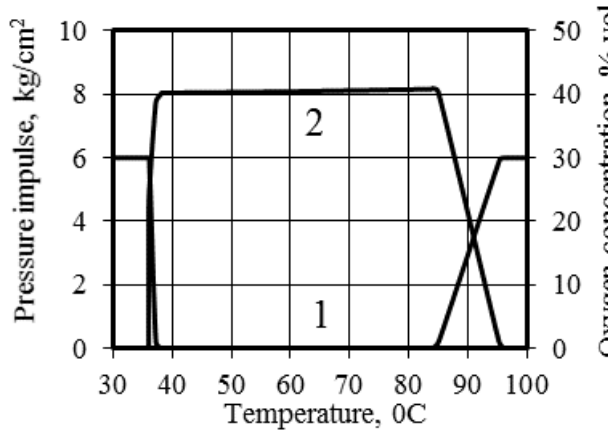

(b)

Fig. 4. Dependence of the temperature limits of combustible mixtures formation and the pressure impulse from oxygen initial concentration in the abovefuel space $25 \%$ vol. $(a)$ and $30 \%$ vol. $(b)$ for fuel RT, Jet A-1: 1 - oxygen concentration; 2 - pressure impulse

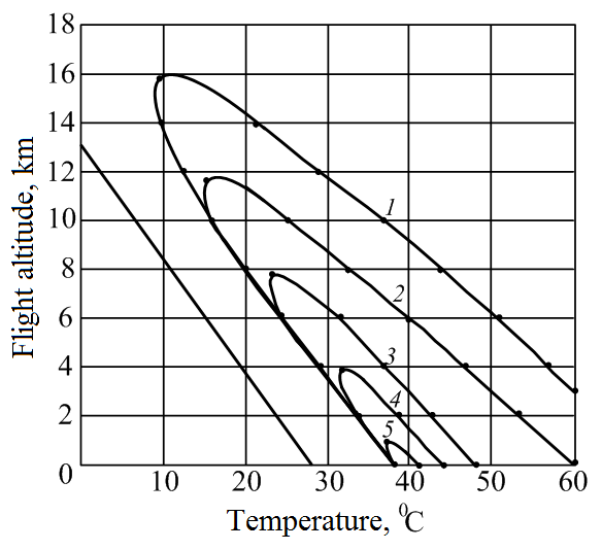

Fig. 5. Temperature limits of combustible mixtures formation depending on the flight altitude and oxygen concentration for fuel RT, Jet A-1: 1 - oxygen volume fraction $25 \% ; 2$ - oxygen volume fraction $21 \%$; 3 - oxygen volume fraction $15 \% ; 4$ - oxygen volume fraction $13 \% ; 5$ - oxygen volume fraction $12 \%$

The obtained results allow to use neutral gas more purposefully and efficiently. There is no need for its use when flying at altitudes above $14000 \mathrm{~m}$.

The ground treatment of fuels to remove dissolved oxygen from them allows maintaining a high level of fire-explosion safety in different modes of the aircraft flight. 
It is possible to conclude in the result of analysis the processes that occur with fuel-air mixtures in fuel tanks during the aircraft flight, that these mixtures are explosive only on separate stages of the flight.

Aircrafts' fuel tanks filled in with fuel RT or Jet A-1 will be explosive only if fuel temperature will be higher than $38-40{ }^{\circ} \mathrm{C}$, i.e., the temperature of the flash point of fuel at oxygen concentration in the abovefuel spaceis $21 \%$ vol. Such temperatures of fuel-air mixture can only be achieved in countries with hot climate, as the experience of operating aviation equipment shows.

With increasing flight altitude the fuel temperature does not change significantly in the first 30-40 minutes and its impact on the air solubility and the temperature limits of the fuel flash is not noticeable. External pressure is the main factor determining fire-explosion danger at this flight stage. The external pressure decrease causes emission of the diluted air from fuel, which leads to an increase of oxygen and fuel vapor concentrations in the above fuel space. It provides a shift of the temperature limits of combustible mixtures formation to the direction of lower values.

Vibrations and mixing of fuel in tanks, the formation of foam in dynamic conditions lead to expanding temperature limits of explosive mixtures due to the shift of lower temperature limit towards lower temperatures and despite the fuel temperature decrease, the lower concentration limit of explosive danger is reached. It is $0,6 \%$ vol. for fuels RT and Jet A-1 at altitudes $4000-5000 \mathrm{~m}$.

During the horizontal flight of a supersonic plane, the fuel temperature exceeds $100{ }^{\circ} \mathrm{C}$ in the fuel system, and sometimes can reach $135-200{ }^{\circ} \mathrm{C}$. As practice shows, the dissolved air emits from fuel gradually when an aircraft climbs in altitude, and a sudden emission of a significant amount of dissolved gases takes place at altitudes greater than $8000 \mathrm{~m}$. This leads to increase of oxygen concentration in the above fuel space and to increase the fire-explosion danger of fuel tanks at the initial period of the horizontal flight. The vapor concentration increases due to the intense fuel evaporation, and fuel-air mixtures in fuel tanks become fire safe when it reaches $4,5 \% \mathrm{vol}$.

The fuel temperature decreases with reducing the altitude of a supersonic plane, and the fuel space becomes again explosive at temperature $58{ }^{\circ} \mathrm{C}$ for fuels RT and Jet A-1, because it is in the zone of the upper temperature limit of the explosion danger.

Thus, the most dangerous parts of the flight are the climbing in an altitude with the initial period of the horizontal flight and the aircraft lowering from the point of view of the formation of an explosive concentration of fuel vapor with air in the above fuel space of fuel tanks. That is why one of the possible ways to protect fuel tanks from explosion may be the pre-flight fuel preparation in order to remove both dissolved oxygen and oxygen located in the above fuel space.

The process of fuel cooling in an aircraft tanks occurs during long term flights with a subsonic speed. The highest rate of fuel temperature decreasing $\left(10-20{ }^{\circ} \mathrm{C}\right.$ per hour) is observed in the first hours of a flight.

Then the cooling rate is reduced to $5{ }^{\circ} \mathrm{C}$ per hour, and the fuel temperature can decrease to minus $43{ }^{\circ} \mathrm{C}$ at an altitude of $10-12 \mathrm{~km}$ at environment temperatures minus $75^{\circ} \mathrm{C}$.

It is possible to conclude analyzing this data, that fire dangerous flight field is climbing an aircraft to altitude.

The concentrations of oxygen and nitrogen in the tank space above fuel during the flight of the aircraft are changed as a result of the emission of air dissolved in the fuel. Numerous tests had shown that the fuel in the Jet A-1 under normal conditions contains about $16 \%$ of dissolved air, while oxygen concentration is about $5,25 \%$ by volume and the nitrogen concentration $-10,75 \%$ (V.) At aircraft altitude raising the dissolved air is released, and the oxygen concentration in the tank space above the fuel can theoretically reach $33 \%$ (V.) via a lower solubility of oxygen in hydrocarbons of fuel compared to nitrogen.

Experimental tests regarding to the amount of dissolved gases in the fuel as a function of the altitude of the aircraft had shown that under static conditions at rate of climb close to the performance, there arises a significant disagreement between the amount of allocated dissolved gases and those were calculated according to Henry's law. During the experiment was observed the 
growth (Fig. 6) of gas emissions delay, and at the increase of the rate of climb this delay had grown too.

It should be noted that at actual flight real conditions, in presence of aircraft evolution and vibration, the delay of dissolved gases release from fuel while having a complex character generally decreases. There is an opportunity to determine theoretically the dependence of oxygen content in the formerly dissolved gases that were emitted depending on the ratio of the fuel volume and over fuel space volume as a function of aircraft climb altitude. In this case we assume that the temperature of fuel and gas is constant.

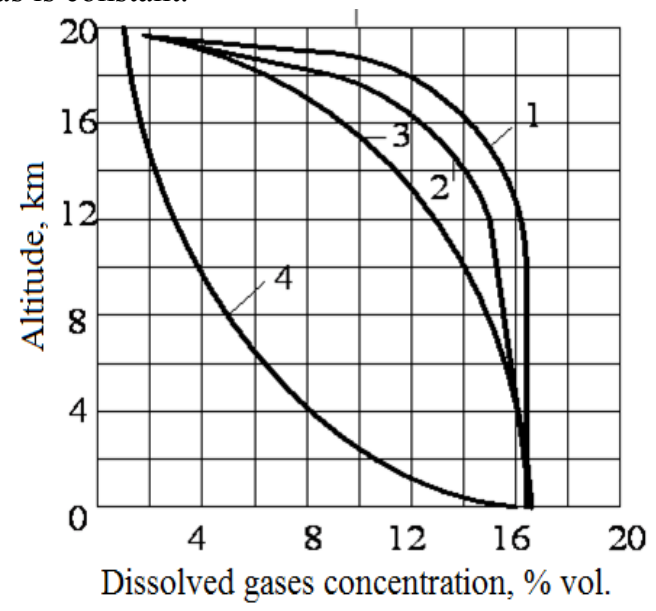

Fig. 6. Dependence of the dissolved air amount in the Jet A-1 fuel, altitude and aircraft rate of climb (Vy): $1-\mathrm{Vy}=75 \mathrm{~m} / \mathrm{s} ; 2-\mathrm{Vy}=45 \mathrm{~m} / \mathrm{s} ; 3-\mathrm{Vy}=15 \mathrm{~m} / \mathrm{s} ; 4-$ according the Henry's law

Then the amount of dissolved gases that are released when changing pressure according to Henry's law, is:

$$
V_{\mathrm{i}}=V_{\mathrm{o}} \cdot\left(1-P_{\mathrm{f}} / P_{\mathrm{o}}\right)
$$

where $\mathrm{V}_{\mathrm{o}}$ - initial volume of dissolved gas, $\mathrm{m}^{3} ; \mathrm{P}_{\mathrm{o}}, \mathrm{P}_{\mathrm{f}}-$ the initial and final pressure, $\mathrm{kPa}$.

At an aircraft climb in altitude the expanding of escaping gases takes place, the volume of which equals to:

$$
V_{\mathrm{i}}=V_{\mathrm{o}} \cdot\left(P_{\mathrm{o}} / P_{\mathrm{f}}-1\right)
$$

Quantity of oxygen in the above fuel space in tank can be determined by the formula:

$$
C \cdot V_{\mathrm{t}}=21 \cdot V^{\prime}+33 \cdot V_{\mathrm{t}}^{\prime}
$$

where $C, 21,33$ - the oxygen concentration in the gas, $\%$ vol .; $V_{\mathrm{t}}$ - total above fuel space, $\mathrm{m}^{3} ; V^{\prime}-$ part of the air space of the tank, $\mathrm{m}^{3} ; V_{\mathrm{t}}$ - part of above fuel space occupied by the gas released from the fuel, $\mathrm{m}^{3}$.

Assuming that under normal conditions, the amount of air in the Jet A-1 fuel reaches $16 \%$, i.e. $V_{\mathrm{o}}=0.16 V_{\mathrm{f}}$ and $V^{\prime}=V_{\mathrm{i}}-V_{\mathrm{i}}$, and using equation (2) represented by formula (3), and after transformations we obtain the oxygen concentration in a mixture:

$$
C=21+1,92 \cdot V_{\mathrm{i}} / V_{\mathrm{t}} \cdot\left(P_{0} / P_{\mathrm{f}}-1\right),
$$

Fig. 7. demonstrates the theoretical dependence of oxygen content in the above fuel space in the aircraft tank as a function of tank fuel filling in and of altitude. Oxygen concentration reaches $33 \%$ vol. in the above fuel space at $70 \%$ filling of the fuel tank with climbing in altitude of $10000 \mathrm{~m}$. 


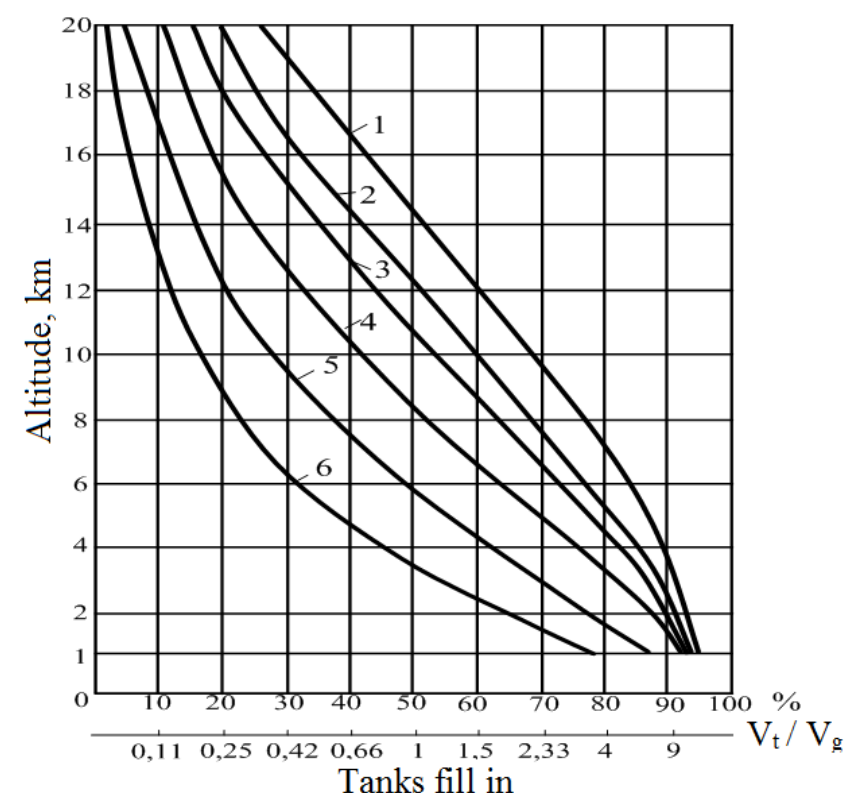

Fig. 7. Theoretical dependence of oxygen concentration in the above fuel space from the tank volume filled with fuel and altitude of an aircraft:

$1-\mathrm{O}_{2}-33 \% ; 2-\mathrm{O}_{2}-29 \% ; 3-\mathrm{O}_{2}-27 \% ; 4-\mathrm{O}_{2}-25 \% ; 5-\mathrm{O}_{2}-23 \% ; 6-\mathrm{O}_{2}-22 \%$

At $20 \%$ the fuel tank filling (the ratio $V_{\text {gas }} / V_{\text {fuel }}=4$ ) and at the climbing rate $5 \mathrm{~m} / \mathrm{s}$ an increase of oxygen concentration occurs above $21 \%$ vol. after altitude of $4000 \mathrm{~m}$ (Fig. $8 a$ ). This suggests that the release of dissolved air from the fuel does not occur immediately after take-off of the aircraft, but during the subsequent ambient pressure drop.

Further tests with various fuel tank filling and at different aircraft climbing rate also indicate an air release delay from the fuel at lift to the designed altitude. Oxygen concentration in the above fuel space increases to $21,7 \%$ when reaching altitude $10000 \mathrm{~m}$. Oxygen concentration increases to $22,3 \%$ while maintaining the tank for $30 \mathrm{~min}$ at this altitude. Oxygen concentration is reduced in tanks at decreasing the aircraft altitude, a dilution of the gas mixture proceeds there in the result of the inflow of outside air into above fuel space. Oxygen concentration is leveled to $21 \%$ vol. at reaching altitude of $4000 \mathrm{~m}$.

Oxygen concentration in the above fuel space increases to $21,5 \%$ from altitude $4000 \mathrm{~m}$ to $10000 \mathrm{~m}$ when the climbing rate is $20 \mathrm{~m} / \mathrm{s}$ (Fig. 8 b).

Some smaller amount of dissolved in the fuel air is released with the climbing rate increase, and when it reaches an altitude of 10000 meters, therefore occurs a smaller concentration of oxygen in the above fuel space. But when the tank is exposed to the altitude $10000 \mathrm{~m}$, the oxygen concentration has been increased to $22,5 \%$ vol.

Increase in the oxygen concentration up to $22,5 \%$ occurs from altitude $4000 \mathrm{~m}$ to $10000 \mathrm{~m}$ (Fig. $9 a$ ) at $40 \%$ filled fuel tank (the ratio $\mathrm{V}_{\mathrm{i}} / \mathrm{V}_{\mathrm{t}}=3 / 2$ ) and the climbing rate $5 \mathrm{~m} / \mathrm{s}$. The further release of dissolved gases takes place when keeping tank at an altitude of 10000 meters and in this case oxygen concentration increases to $24,3 \%$ vol. Oxygen content is reduced to about $21,1 \%$ in the result of reducing the altitude from 10000 meters to the ground level. A similar result was obtained with a chosen climbing rate of tank equal $20 \mathrm{~m} / \mathrm{s}$ (Fig. 9b). However, oxygen concentration increases by a larger amount - from 22,2 to $24,3 \%$ vol. at maintaining the tank at an altitude of 10000 meters. 


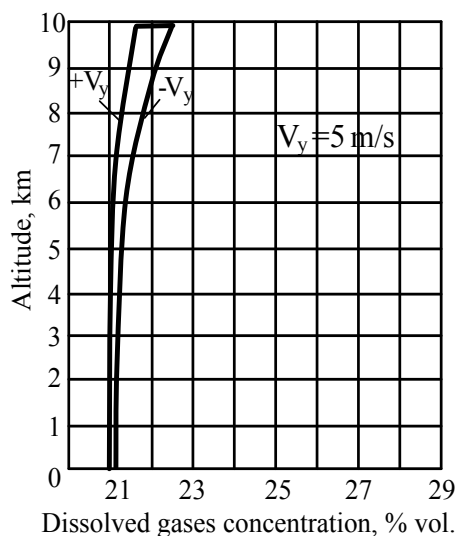

(a)

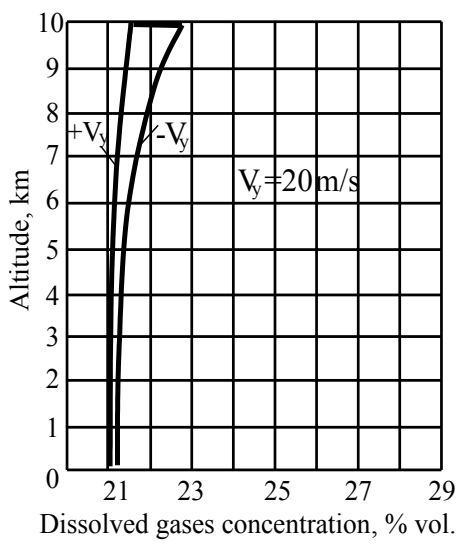

(b)

Fig. 8. Change of oxygen concentration in the above fuel space as the tank is risen to the altitude and at $20 \%$ fuel tank filling

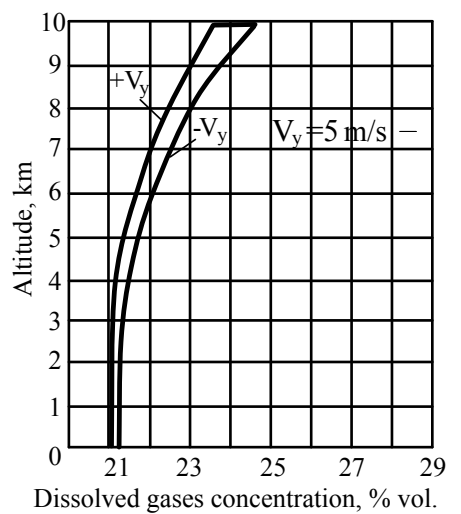

(a)

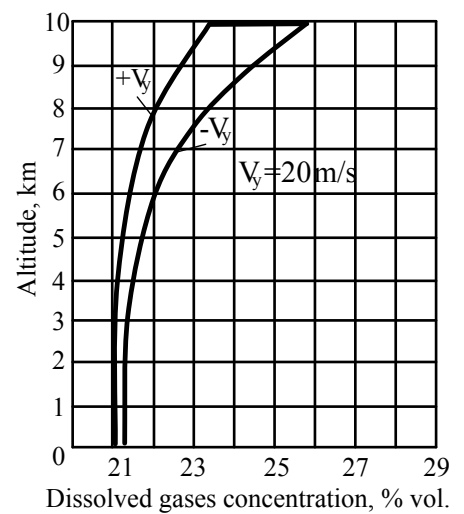

(b)

Fig. 9. Change of oxygen concentration in the above fuel space as the tank is risen to the altitude and at $40 \%$ fuel tank filling

Oxygen concentration increases to $24,3 \%$ in the above fuel space for altitudes from $4000 \mathrm{~m}$ to $10000 \mathrm{~m}$, at $70 \%$ fuel tank filling and at the climbing rate $5 \mathrm{~m} / \mathrm{sec}$ (Fig. 10). Oxygen concentration increases to $25,8 \%$ vol. when maintaining the tank at altitude of $10000 \mathrm{~m}$. Oxygen concentration is reduced to $21,3 \%$ vol. (Fig. 10a) at aircraft descending. As the aircraft climbing rate $20 \mathrm{~m} / \mathrm{s}$ while maintaining the fuel tank at an altitude $10000 \mathrm{~m}$ the oxygen content is increased from $23,8 \%$ to 28 vol. (Fig. $10 b$ ).

It has been established that the temperature limits of the explosive fuel-air mixtures formation in aircrafts fuel tanks depend on oxygen volume fraction in the above fuel space. The pressure impulse increases from the explosion of fuel-air mixture, the lower temperature limit of the flash shifts towards lower temperatures and simultaneously the temperature range of explosive danger considerably expands with an increase of oxygen concentration, due to the evolving of dissolved air from fuel. There is no intense release of oxygen dissolved in fuel during the aircraft climbing in the altitude $3000-4000 \mathrm{~m}$. 


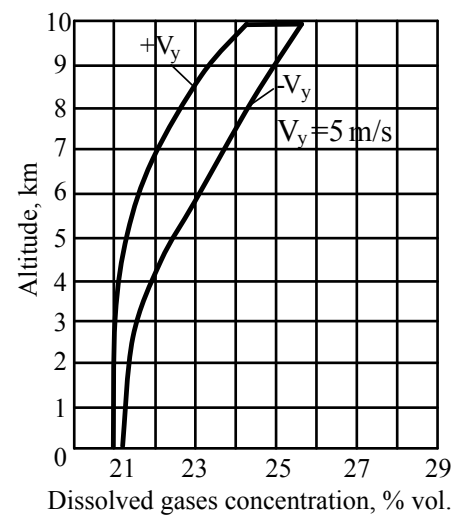

(a)

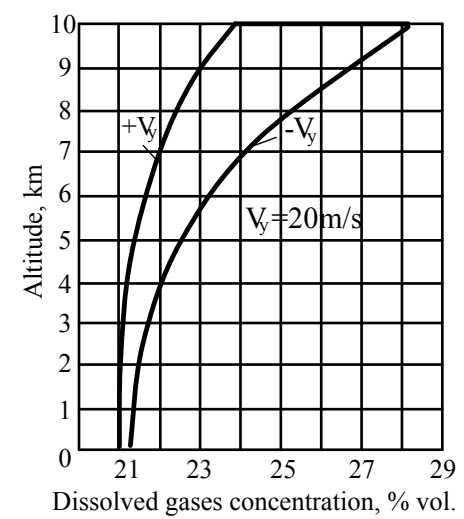

(b)

Fig. 10. Change of oxygen concentration in the above fuel space as the aircraft tank is risen to the altitude and at $70 \%$ fuel tank filling

It has been determined that temperature limits of combustible mixtures formation with increasing flight altitude are narrowed and shifted towards lower temperatures. The most dangerous flight conditions for subsonic airplanes are the fuel temperature from 12 to $74{ }^{\circ} \mathrm{C}$ and the flight altitude to $12000 \mathrm{~m}$. Explosive fuel vapor and air oxygen mixtures are formed in the above fuel space under these conditions.

It has been established that the flash does not occur in the ground conditions when oxygen concentration in the fuel-air mixture reaches $12 \%$ vol. It has been determined that with the increase of the flight altitude, the temperature limit combustible mixtures formation is narrowed and shifted towards lower temperatures. The explosive area for subsonic aircrafts is $38-58{ }^{\circ} \mathrm{C}$ in the ground conditions, $29-44{ }^{\circ} \mathrm{C}$ at an altitude $5000 \mathrm{~m}$ and $13-36{ }^{\circ} \mathrm{C}$ at an altitude $10000 \mathrm{~m}$ if oxygen concentration is $21 \%$ vol.

It has been established that the maximum permissible concentration of oxygen in aircraft's fuel tanks increases depending on the flight altitude. Thus, it is $12 \%$ vol. at ground conditions, $15 \%$ vol. - at an altitude $5000 \mathrm{~m}, 17 \%$ vol. - at an altitude $10000 \mathrm{~m}$.

It has been determined that explosion of fuel-air mixture is not possible during flights at altitudes above $14000 \mathrm{~m}$.

Thus, at aircraft climbing at definite altitude in the above fuel space of tanks the increase of oxygen concentration takes place owing to the emission of gases dissolved in the fuel. The intensity and the magnitude of this increase depend on the degree of a fuel tank filling, on an altitude and a climbing rate.

Based on these studies, the staff of the National Aviation University had developed technical solutions that allow influencing the oxygen content in the above fuel space in the aircraft tanks that will increase fire-explosion safety and also the reliability of the fuel system.

\section{РЕФЕРАТ}

Валерій Сфименко, Тетяна Кравчук, Лідія Ковшун, Наталія Атаманенко

Наиіональний авіаційний університет, е.valerij.ua@gmail.com

\section{ВПЛИВ КОНЦЕНТРАЦЇ̈ КИСНЮ НА ПОЖЕЖОБЕЗПЕЧНІСТЬ ПАЛИВНИХ СИСТЕМ} ПОВІТРЯНИХ СУДЕН

Метою роботи $є$ забезпечення пожежовибухобезпечності та поліпшення експлуатаційних показників якості реактивних палив.

Об'єктом дослідження є процеси розчинення повітря (кисню) в паливах, визначення його концентрації в надпаливному просторі паливних баків повітряних суден та утворення безпечних до 
загоряння паливоповітряних сумішей. Ця проблема $є$ актуальною з огляду необхідності забезпечення хіммотологічної надійності паливних систем авіаційної техніки.

Предметом дослідження є пожежовибухобезпечність реактивних палив PT (Jet A-1) та її зв'язок 3 наявністю розчинених у них газів і газів, що знаходяться в надпаливному просторі паливних баків.

Визначені температурні межі утворення горючих паливно-повітряних сумішей залежно від висоти польоту повітряного судна, температури та зміни концентрації кисню в надпаливному просторі.

Ключові слова: реактивні палива, вміст кисню, паливо-повітряні суміші, пожежовибухобезпечність.

\section{PЕФЕРАТ}

Валерий Ефименко, Татьяна Кравчук, Лидия Ковшун, Наталья Атаманенко Национальный авиачионный університет, е.valerij.иа@gmail.com

\section{ВЛИЯНИЕ КОНЦЕНТРАЦИИ КИСЛОРОДА НА ПОЖАРОБЕЗОПАСНОСТЬ ТОПЛИВНЫХ СИСТЕМ ВОЗДУШНЫХ СУДОВ}

Целью работы является обеспечение пожаровзрывобезопасности и улучшения эксплуатационных показателей качества реактивных топлив.

Объектом исследования являются процессы растворения воздуха (кислорода) в топливах, определение его концентрации в надтопливном пространстве топливных баков воздушных судов и образование безопасных к возгоранию топливовоздушных смесей. Эта проблема является актуальной ввиду необходимости обеспечения химмотологической надежности топливных систем авиационной техники.

Предметом исследования является пожаровзрывобезопасность реактивных топлив PT (Jet A-1) и её связь с наличием растворенных в них газов и газов, находящихся в надтопливном пространстве топливных баков.

Определены температурные пределы образования горючих топливно-воздушных смесей в зависимости от высоты полета воздушного судна, температуры и изменения концентрации кислорода в надтопливном пространстве.

Ключевые слова: реактивные топлива, содержание кислорода, топливо-воздушные смеси, пожаровзрывобезопасность.

\section{ABSTRACT \\ Valeriy Yefymenko, Tetiana Kravchuk, Lidiya Kovshun, Natalya Atamanenko National Aviation University, e.valerij.ua@gmail.com}

\section{THE INFLUENCE OF OXYGEN CONCENTRATION ON THE FIRE SAFETY}

OF AIRCRAFTS FUEL SYSTEMS

The aim of the work is to provide fire-explosion safety and to improve performance indicators of the jet fuels quality.

The object of the study is the processes of air (oxygen) dissolving in fuels, determination of its concentration in the above fuel space of fuel tanks and creation of safe to ignite fuel-air mixtures. This problem is relevant due to the need to ensure the chemmotological reliability of aircrafts fuel systems.

The subject of the study is fire-explosion safety of jet fuels RT (Jet A-1) and its connection with the presence of dissolved gases and gases in the above fuel space in fuel tanks.

It has been determined the temperature limits of the formation of combustible fuel-air mixtures depending on the aircraft's flight altitude, temperature and changes in oxygen concentration in the abovefuel space.

Key words: jet fuels, oxygen content, fuel-air mixtures, fire-explosion safety.

\section{REFERENCES}

1. Emission of oxygen dissolved in fuel at aircraft climb / [V. Iefymenko, E. Novoselov, A. Kustovska et al.]. // Aviation in the XXI-st century: the eight world congress (Kyiv, 10-12 October, 2018). - K.: NAU, 2018. - P. 5.

2. Results of 1/4-scale experiments, vapor simulant and liquid Jet A tests: Explosion Dynamics Laboratory Report / [J. E. Shepherd, J.C. Krok, J.J. Lee et al.]. - California Institute of Technology. - FM98-6. - California, July 1998. 
3. Yefymenko $V . V$. Influence of processing of reactive fuels with neutral gases on their fire safety, thermal oxidation stability and cavitation properties: Ph. D. thesis in eng.: spec. 05.17.07 «Chemical technology of fuels and lubricants» / Iefymenko V. V. - K.:2007. - 172 p.

4. Aviation Chemmotology: Fuel for Aviation Engines. Theoretical and engineering basics of application: textbook / N. S. Kulik, A. F. Aksenov, L. S. Yanovsky, C. V. Boichenko. - K.: NAU, 2015. - 560 p.

DOI: doi.org/10.18372/38233

UDC: $621.892 .6: 504(043.2)$

\subsection{IDENTIFICATION AND ASSESSMENT OF BIOLOGICAL RISK OF AVIATION FUEL SUPPLY}

\section{Iryna Shkilniuk ${ }^{1}$, Sergii Boichenko ${ }^{1}$, Tetiana Kondratiuk ${ }^{3}$, Nataliia Shevchuk $^{2}$}

Aviation fuel supply exists as much as aviation is more than a hundred years. Fuel is the blood of an aircraft. The mass of fueled jet fuel is up to $70 \%$ of the maximum take-off weight of modern aircraft. The main link in all civil aviation activities is flight safety. The most important condition for ensuring the safety of flights is the use of aircraft in the range of expected operating conditions, taking into account operational limitations established in the norms of airworthiness.

Now ICAO is disturbed formed by the world tendency of entering of contaminated aviation fuel in airport. Many documents ICAO, IATA and Joint Inspection Group focuses on pollution fuels. ICAO issued a directive DOC 9977 «Guide to the supply of aviation fuel in civil aviation» and IATA issued EI/JIG STANDARD 1530 «Quality assurance requirements for the manufacture, storage and distribution of aviation fuels to airports». The essence of these documents is that all parties involved are jointly responsible for ensuring the quality, purity and possibility of quality control at every stage of production, supply and operation of aviation fuel.

Fuel and air machinery loss during operation are major aircraft losses for modern aircraft. The main factors and parameters that determine the indicated losses in operation are flight path, speed and altitude; equipment reliability; fuel conditioning.

The study of theoretical and practical aspects of risk, its analysis and assessment is becoming increasingly relevant, because the risk in today's economic environment has a significant impact on the results of enterprises.

The active study on microbial growth in the composition of petroleum fuels began in the USA during the creation of jet aircraft.

During the creation of jet aviation in the USA, began active study of questions connected with microorganisms' development in oil fuels. The work on this question in our country mainly was to determine fuels biostability in laboratory conditions. Purposeful researches of fuels biostability in operating conditions were not conducted practically [1].

In 1956, the United States Air Force recognized that its widely-used JP-4 fuels were microbial contaminated when Air Force B-47 and KC-97 flight operations were affected. Two years later, a B-52 crash was directly attributed to clogging of fuel system screens and filters by some form of fuel contamination. In that same year, the Wright Air Development Center determined that sludge accumulation in tanks used to store kerosene-type fuels was a common occurrence [2].

More instances of contamination and corrosion surfaced in the late 1950's and early 1960's and reached near epidemic proportions in storage tanks and aircraft fuel cells at various locations. At the beginning of 1962, approximately 52 governmental and non-governmental agencies were involved in various phases of research on microbiological contamination of fuels.

The modern world legislation raises the level of requirements for quality aviation fuels. In 2012, the International Civil Aviation Organization has developed directive 9977/AN 489 